\title{
Preparation of (5R)-4,8-Dimethylbicyclo[3.3.0]oct-1(8),3-dien-2-one from (-)-Limonene oxide. A Novel Intermediate to the Synthesis of 4-5-5 Fused Tricarbocyclic Core Present in Terpenic Natural Products
}

\author{
Diego S. Pisoni, Daniel B. Silva ${ }^{a}$, Rossana A. Schenato ${ }^{b}$ and Marco A. Ceschi ${ }^{*, a}$ \\ ${ }^{a}$ Instituto de Química, Universidade Federal do Rio Grande do Sul, Av. Bento Gonçalves, 9500, Campus do Vale, \\ 91501-970 Porto Alegre - RS, Brazil \\ ${ }^{b}$ Faculdade de Química, Pontifícia Universidade Católica do Rio Grande do Sul, Av. Ipiranga, 6681, 90619-900 \\ Porto Alegre - RS, Brazil
}

\begin{abstract}
Este trabalho refere-se à síntese enantiosseletiva da dienona (5R)-4,8-dimethylbicyclo[3.3.0]oct1(8),3-dien-2-one. Este intermediário, pode ser reconhecido como um bloco de construção versátil para a síntese de uma grande variedade de compostos com esqueleto biciclo[3.3.0]octano. A estratégia sintética empregada aqui faz uso da reatividade invertida de um precursor cianoidrina TMS-éter, como equivalente de ânion acila, para promover uma reação de alquilação intramolecular. A síntese formal do (-)-kelsoeno foi realizada pela preparação do intermediário avançado $(1 R, 5 S, 8 R)-4,8$ dimethylbicyclo[3.3.0] oct-3-en-2-one, a partir da hidrogenação seletiva do composto intitulado $(5 R)$ 4,8-dimethylbicyclo[3.3.0]oct-1(8),3-dien-2-one.
\end{abstract}

This paper describes the conversion of the readily available (-)-limonene oxide to the new $(5 R)$ 4,8-dimethylbicyclo[3.3.0]oct-1(8),3-dien-2-one. This compound holds the prospect of serving as a useful chiral building block or intermediate to prepare a variety of compounds having a bicyclo[3.3.0]octane framework. The synthetic strategy made use of the umpolung reactivity of cyanohydrin TMS ether, as an acyl anion equivalent, in order to promote intramolecular alkylation. The formal synthesis of (-)-kelsoene was achieved by preparing a known advanced intermediate $(1 R, 5 S, 8 R)$-4,8-dimethylbicyclo[3.3.0]oct-3-en-2-one via selective hydrogenation of the named compound (5R)-4,8-dimethylbicyclo[3.3.0]oct-1(8),3-dien-2-one.

Keywords: limonene oxide, bicyclo[3.3.0]octane, chiral, building block

\section{Introduction}

There is currently considerable interest in the synthesis of optically active bicyclo[3.3.0]octane containing one or more functional group(s) at suitable position(s) for synthetic purposes, as these compounds have been widely accepted as an efficient chiral building block or intermediate for preparing both natural and nonnatural biologically active compounds. ${ }^{1}$ The tricyclo[6.2.0.0 $\left.0^{2,6}\right]$ decane framework $\mathbf{1}$, constituted through the linear fusion of 4-5-5-membered carbocyclic rings, has been encountered only sporadically among natural products. ${ }^{2}$ Among the very few known examples of terpenoid natural products based on this ring system are sulcatine $G(2)$, from a Basidiomycetes fungus, ${ }^{3,4}$ poduran (3), from the springtail Podura aquatica ${ }^{5}$ and kelsoene 4, from the

*e-mail: mceschi@iq.ufrgs.br marine sponge Cymbastela hooperi ${ }^{6}$ as well as from the liverworts Ptychanthus striatus, ${ }^{7}$ Calypogeia muellerian ${ }^{8}$ and Tritomaria quinquedentata. ${ }^{9}$

In 1999, Nabeta et al., on the basis of ${ }^{1} \mathrm{H}$ NMR experiments carried out on two diastereomeric substances derived from (+)-kelsoene, concluded that the natural product has the absolute configuration (-)-4 (Figure 1). ${ }^{10}$ However, in 2001, Schultz ${ }^{11}$ and Mehta ${ }^{12}$ independently demonstrated, on the basis of synthetic studies, that this conclusion was incorrect and that, in fact, the absolute configuration of natural (+)-kelsoene is as depicted in $\mathbf{4}$. Starting from $(R)-(+)$-pulegone, Schultz proceeded with the synthesis of nonnatural (-)-kelsoene (4) and Mehta achieved the enantioselective synthesis of both natural (+)-4 and nonnatural (-)-4 kelsoene by lipase-catalyzed resolution of endo,endo-cis-bicyclo[3.3.0]octane-2,6-diol. In addition, $( \pm)$-kelsoene was constructed via a 15 -step synthetic sequence starting from cyclopent-2-en-1-one and 


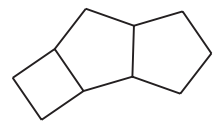

1

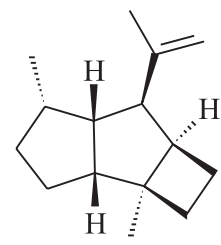

4 [natural

$(+)$-kelsoene]

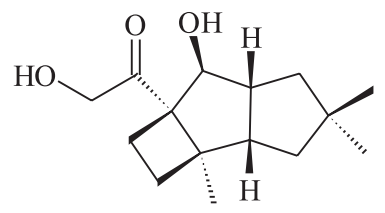

2

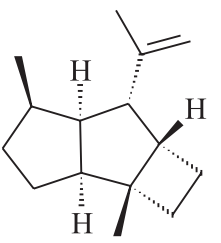

ent-4

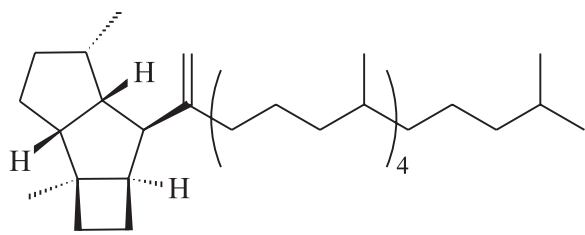

3

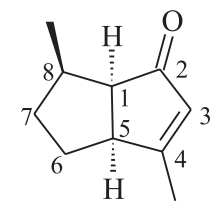

$(1 R, 5 S, 8 R)-5$

Figure 1. Natural and nonnatural products based on tricyclo[6.2.0.0 $\left.0^{2,6}\right]$ decane framework $\mathbf{1}$ and precursor 5 .

the bifunctional reagent lithium cyano(4-chlorobut-1-en2-yl)cuprate by Piers. ${ }^{13}$

The three different strategies for the synthesis of kelsoene described so far employ the common precursor $\mathbf{5}$ in its racemic or enantiopure form at an early stage of the synthesis.

In this paper, we wish to describe the enantiospecific preparation of the new bicyclic $\alpha, \beta$-unsaturated enone (-)-6 from (-)-limonene oxide (10) (Scheme 1). We also studied the selective catalytic hydrogenations of (-)-6 to access (-)-5, the intermediate for the synthesis of (-)-kelsoene (ent-4) and poduran (3).

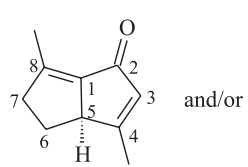

$(R)-6$

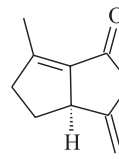

$(R)-7$

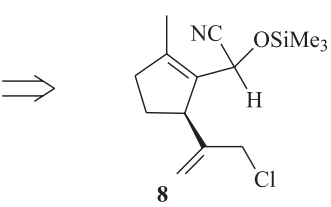<smiles>C=C(CCl)C(CC)CC=O</smiles>

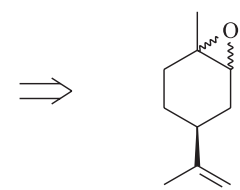

10
Scheme 1. Retrosynthetic analysis for (R)-6 from (-)-limonene oxide.

From the retrosynthetic perspective, we envisioned that the pentalenone core $\mathbf{6}$ and/or 7 would be accessible from the pentacyclic cyanohydrin TMS ether $\mathbf{8}$, by a StorkTakahashi intramolecular alkylation, followed by decyanation. ${ }^{14-16}$ The intermediate $\mathbf{8}$ in turn could be accessed from the acyclic keto aldehyde precursor 9 by aldol condensation and silyloxy nitrile conversion of the resulting cyclic aldehyde. The precursor 9 could be prepared from the commercially available (-)-limonene oxide (10), as reported in the literature. ${ }^{17-20}$

\section{Results and Discussion}

The synthesis of (-)-6 started with the preparation of the enantiomerically pure keto aldehyde (-)-9 from (-)limonene oxide 10, employing previously developed methodology. ${ }^{18-20}$ (-)-Limonene epoxide $\mathbf{1 0}$ reacts cleanly with $\mathrm{HOCl}$ to afford 10-chlorolimonene oxide $\mathbf{1 1 .}{ }^{18}$ Subsequent acid-catalyzed hydrolysis of epoxyde function to diol 12, followed by oxidative cleavage with sodium metaperiodate, leads to the keto aldehyde (-)-9 in $48 \%$ overall yield from (-)-10. ${ }^{19,20}$

Aldehyde 13 was obtained from (-)-9 by aldol condensation with piperidine-acetic acid, in $44 \%$ yield. ${ }^{20}$ The unstable conjugated aldehyde $\mathbf{1 3}$ thus obtained was cleanly converted to the cyanohydrin TMS ether $\mathbf{8}$ by addition of $\mathrm{Me}_{3} \mathrm{SiCN}$ in the presence of catalytic amount of KCN/18-crown-6 complex. The intramolecular alkylation of cyanohydrin TMS ether $\mathbf{8}$ to $\mathbf{1 4}$ was immediately carried out without purification, based on Stork-Takahashi procedure. ${ }^{14-16}$ In our case, we found higher yield performing the cyclization reaction at lower temperature and reduced excess of base. The crude product 14 was treated with tetra- $n$-butylammonium fluoride in aqueous THF at room temperature for 3 days to give only (-)-6 with the endocyclic C3-C4 double bond, after chromatographic purification. Attempts to isolate thermodynamically less stable exocyclic olefin isomer 7 resulted in failure. When the decyanation of $\mathbf{1 4}$ was conducted at shorter reaction time and lower temperature, 


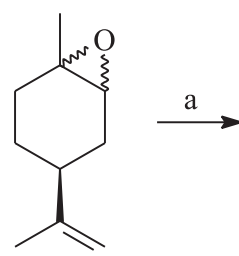

10

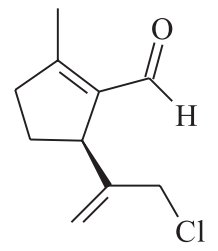

13

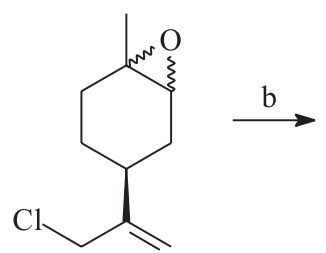

11<smiles>C=C(CCl)C1CC[C@@](C)(O)[C@H](O)C1</smiles>

12<smiles>C=C(CCl)C(CC=O)CC(C)=O</smiles>

9

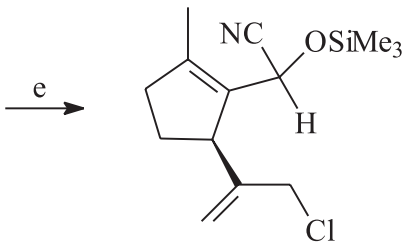

8

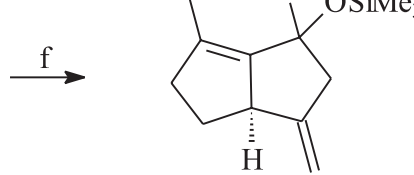

14

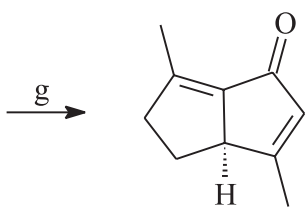

$(5 R)-6$

a: $\mathrm{HOCl}$, aq. $\mathrm{CH}_{2} \mathrm{Cl}_{2}, \mathrm{rt}, 1.5 \mathrm{~h}$; b: $1 \% \mathrm{H}_{2} \mathrm{SO}_{4} 0{ }^{\circ} \mathrm{C}$ to rt, c: $\mathrm{NaIO}_{4}, \mathrm{THF} / \mathrm{H}_{2} \mathrm{O}, 0{ }^{\circ} \mathrm{C}, 3$ days $(48 \%$ yield over three steps); d: piperidine, $\mathrm{HOAc}$, benzene, reflux, $1 \mathrm{~h}, 44 \%$; e: $\mathrm{Me}_{3} \mathrm{SiCN}$, cat. KCN/18-crown-6 ether complex, $0{ }^{\circ} \mathrm{C}, 2 \mathrm{~h}$; f: $\operatorname{LiN}\left(\mathrm{SiMe}_{3}\right)_{2}, \mathrm{THF}, \mathrm{rt}, 1.5 \mathrm{~h} ; \mathrm{g}: n-\mathrm{Bu} \mathrm{N}_{4} \mathrm{~N}^{+} \mathrm{F}, 10 \%$ aqueous THF, rt, 3 days (75\% based on three steps from starting aldehyde 13).

\section{Scheme 2.}

rapid isomerization took place, as observed by ${ }^{1} \mathrm{H}$ NMR spectroscopy.

Pentalenone (-)-6 was them subjected to catalytic hydrogenation at $1 \mathrm{~atm}$ over $10 \% \mathrm{Pd} / \mathrm{C}$ in $\mathrm{EtOH}$ at $25^{\circ} \mathrm{C}$ and the reaction course was examined by ${ }^{1} \mathrm{H}$ NMR spectroscopy and CG analysis. Running the hydrogenation reaction for $24 \mathrm{~h}$, formation of $\mathbf{5}$ and $\mathbf{1 5}$ was observed in a ratio of approximately. 1.7:1. The rapid isomerization of $\mathbf{6}$ to $\mathbf{1 5}$ during the hydrogenation reaction is supported by ${ }^{1} \mathrm{H}$ NMR data comparisons between isolated 6 and the mixture containing $\mathbf{5}$ and $\mathbf{1 5}$. The singlet olefinic signal H-3 in the mixture containing $\mathbf{5}$ and $\mathbf{1 5}$ appears at $\delta 5.81$ and $5.68 \mathrm{ppm}$, respectively, while the corresponding resonance in 6 is at $5.88 \mathrm{ppm}$. In the ${ }^{1} \mathrm{H}$ NMR spectrum of 6, the signals assigned to vinyl methyl hydrogens were observed at $\delta 2.08(\mathrm{~s}, 3 \mathrm{H})$ and $2.10 \mathrm{ppm}(\mathrm{s}, 3 \mathrm{H})$. In the mixture of $\mathbf{5}$ and $\mathbf{1 5}$, two vinyl methyl protons were observed at 2.01 and $2.04 \mathrm{ppm}$ for each compound and a doublet observed at $1.02 \mathrm{ppm}(6.8 \mathrm{~Hz})$ is assigned to C-8 methyl hydrogens. After $35 \mathrm{~h}$ reaction, the conversion of $\mathbf{1 5}$ to $\mathbf{5}$ was essentially complete. At this stage, the reaction was quenched by filtration over celite to afford the crude product in $89 \%$ yield. Because of experimental difficulties, the volatile enone 5 was not purified. ${ }^{1} \mathrm{H}$ NMR spectroscopy and $\mathrm{CG}$ analysis of the crude product presents approximately $78 \%$ of $\mathbf{5}$. The assignments of ${ }^{1} \mathrm{H}$ and ${ }^{13} \mathrm{C}$ in the NMR spectra of the crude product containing $\mathbf{5}$ are further supported by reported data described in the literature. ${ }^{13}$ The addition of hydrogen to both (-)-6 and $\mathbf{1 5}$ is favored by the convex upper face of the molecule; on this basis, the major hydrogenation product, which is the same in the two cases, is endo methyl enone 5. In spite of this, the isomerization of the starting (-)-6 to 15 observed in the hydrogenation reaction was not surprising in view of precedents in the literature, since it is well documented that the cis ring fusion stereochemistry in $\mathbf{1 5}$ is thermodynamically more stable than in precursor (-)-6, and a driving force of approximately $2.4 \mathrm{kcal} / \mathrm{mol}$ has been estimated for related cis-bicyclo[3.3.0]octan-2-ones. ${ }^{21-23}$

Running the hydrogenation reaction with the same catalyst at $810 \mathrm{kPa}$ of hydrogen pressure in $\mathrm{EtOH}$ at $25^{\circ} \mathrm{C}$, for $24 \mathrm{~h}$, gave a mixture of the saturated ketone $\mathbf{1 6}$ and a minor saturated product which was not separable by chromatography on silica gel. The structure of $\mathbf{1 6}$ was supported by the assignments of its ${ }^{1} \mathrm{H}$ and ${ }^{13} \mathrm{C}$ NMR data and comparison with those described in the literature ${ }^{24}$ while the minor saturated component which was not fully characterized in this work is presumably formed by the addition of hydrogen from the more sterically encumbered face of (-)-6.

In summary, we have developed an efficient and stereoselective route toward dienone (-)-6, a versatile building block for the synthesis of natural and nonnatural chiral terpenoids bearing the bicyclo[3.3.0]octane framework. The key strategic feature is the intramolecular alkylation of cyanohydrin TMS ether 8 to 14. In order to demonstrate the applicability of this new intermediate, we have performed the stereoselective hydrogenation of (-)-6 to access (-)-5, which represents the formal total synthesis of sesquiterpene ent-kelsoene (4) and tetraterpene ent- 

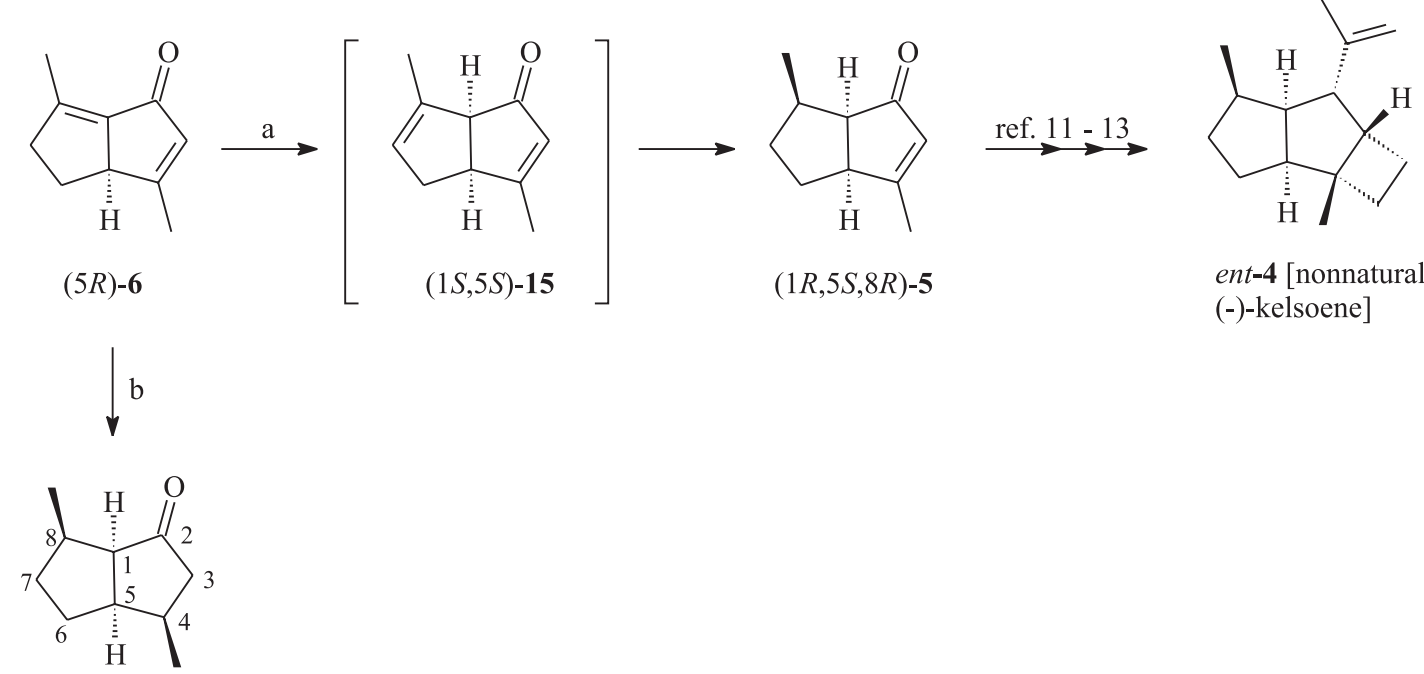

$(1 R, 4 R, 5 R, 8 R)-16$
(major)

Scheme 3. Reagents and conditions: a: $\mathrm{H}_{2}(101 \mathrm{kPa}), 10 \% \mathrm{Pd} / \mathrm{C}, \mathrm{EtOH}, \mathrm{rt}, \mathrm{h}, 90 \%$; b H $\mathrm{H}_{2}(810 \mathrm{kPa}), 10 \% \mathrm{Pd} / \mathrm{C}, \mathrm{EtOH}, \mathrm{rt}, 72 \mathrm{~h}, 90 \%$.

poduran (3). Intermediate (-)-6 was obtained in seven steps and $15.6 \%$ overall yield from (-)-limonene oxide (10). The scaffolding potential of this new building block is currently under study and will be reported in due course.

\section{Experimental}

Melting points were measured on an Electrothermal IA 9100 digital melting point apparatus. IR spectra were measured on a Mattson Galaxy Series FT-IR 3000 (model 3020). ${ }^{1} \mathrm{H}$ and ${ }^{13} \mathrm{C}$ NMR spectra were obtained on a Varian VXR-200. Chemical shifts are expressed as $\delta$ (ppm) relative to TMS as an internal standard and $J$ values are given in $\mathrm{Hz}$. The products were analyzed by GC on a Shimadzu GC-17A Gas Chromatograph, equipped with a FID detector. GC parameters for achiral analysis: injector $230{ }^{\circ} \mathrm{C}$; detector $300{ }^{\circ} \mathrm{C}$; oven $80^{\circ} \mathrm{C}$ for $5 \mathrm{~min}$ then $15^{\circ} \mathrm{C} \mathrm{min}{ }^{-1}$ for $5 \mathrm{~min}$ until $300{ }^{\circ} \mathrm{C}$; column pressure $20 \mathrm{kPa}$, column flow $6.3 \mathrm{~mL}$ $\min ^{-1}$; linear velocity $53.1 \mathrm{~cm} \mathrm{~s}^{-1}$; total flow $138 \mathrm{~mL} \mathrm{~min}^{-1}$; split ratio 1:20; column DB1 $15 \mathrm{~m} \times 0.53 \mathrm{~mm}$ (internal diameter). GC parameters for chiral analysis: injector $250{ }^{\circ} \mathrm{C}$; detector $300{ }^{\circ} \mathrm{C}$; oven $60{ }^{\circ} \mathrm{C}$ for $10 \mathrm{~min}$ then $1{ }^{\circ} \mathrm{C} \mathrm{min}-1$ until $220^{\circ} \mathrm{C}$; column pressure $100 \mathrm{kPa}$, column flow $1.1 \mathrm{~mL} \mathrm{~min}^{-1}$; linear velocity $27.9 \mathrm{~cm} \mathrm{~s}^{-1}$; total flow $41 \mathrm{~mL} \mathrm{~min}^{-1}$; split ratio 1:27; column $\beta$-cyclodextrin $30 \mathrm{~m} \times 0.25 \mathrm{~mm}$ (internal diameter). Optical rotations were measured in a Perkin-Elmer 341 polarimeter with a $0.1 \mathrm{dm}$ cell at a temperature of $20^{\circ} \mathrm{C}$.

Purification by column chromatography was carried out on silica gel 60 (70-230 mesh). Analytical thin-layer chromatography (TLC) was conducted on Merck aluminum plates with $0.2 \mathrm{~mm}$ of silica gel $60 \mathrm{~F}-254$.
(5R)-5-chloroisopropenyl-2-methyl-1-[2(trimethylsilyl)oxyacetonitril]-1-cyclopentene (8)

To a mixture of $650 \mathrm{mg}$ ( $3.52 \mathrm{mmol})$ of aldehyde $\mathbf{1 3}^{20}$ and $0.62 \mathrm{~mL}(4.65 \mathrm{mmol})$ of trimethylsilyl cyanide (TMSCN) was added a catalytic amount of KCN $(4.6 \mathrm{mg})$ and 18-crown-6-complex (18 mg) while stirring under nitrogen atmosphere at $0{ }^{\circ} \mathrm{C}$. After $2 \mathrm{~h}$, excess trimethylsilyl cyanide was removed in vacuo to give $1.02 \mathrm{~g}$ of the crude cyanohydrin TMS ether $\mathbf{8}$, which was used in the next step without further purification. IR (film) $v_{\max } / \mathrm{cm}^{-1}: 3080$, 2960, 2850, 2235, 1640, 1440, 1250 1090, 1060, 905, 870, 850, 750; ${ }^{1} \mathrm{H}$ NMR (200 MHz) $\delta 0.19$ (s, 9H), $1.59-$ $1.82(\mathrm{~m}, 1 \mathrm{H}), 1.89(\mathrm{~s}, 3 \mathrm{H}), 2.05-2.14(\mathrm{~m}, 1 \mathrm{H}), 2.15-2.62$ (m, 2H), 3.59 (bt, 1H), $3.98-4.19$ (m, 2H), 5.05 (s, 1H), $5.09(\mathrm{~s}, 1 \mathrm{H}), 5.27(\mathrm{~s}, 1 \mathrm{H}) ;{ }^{13} \mathrm{C} \mathrm{NMR}(75 \mathrm{MHz}) \delta-0.45,14.4$, 30.0, 37.8, 47.2, 50.2, 57.6, 70.1, 116.0, 130.7, 142.7, 146.6 (for the major diastereomer).

(5R)-4,8-dimethylbicyclo[3.3.0]oct-1(8),3-dien-2-one (6)

A solution of $\mathrm{LiN}\left(\mathrm{SiMe}_{3}\right)$ was prepared by adding 10.6 $\mathrm{mL}$ of $1 \mathrm{~mol} \mathrm{~L}^{-1} \mathrm{BuLi}$ in $2.60 \mathrm{~mL}(12.4 \mathrm{mmol})$ of $\mathrm{HN}\left(\mathrm{SiMe}_{3}\right)$ dissolved in $60 \mathrm{~mL}$ of THF at $0{ }^{\circ} \mathrm{C}$ under nitrogen atmosphere. To this solution was added $1.02 \mathrm{~g}$ (3.52 mmol, based on the starting aldehyde 13 ) of the crude cyanohydrin TMS ether 8 , in $49 \mathrm{~mL}$ of THF over $1 \mathrm{~h}$ at room temperature. The resultant mixture was stirred at the same temperature for $30 \mathrm{~min}$ and poured into a mixture of brine $(100 \mathrm{~mL})$ and $n$-hexane $(78 \mathrm{~mL})$ containing $50 \mathrm{~g}$ of ice. The organic layer was separated and extracted with $n$-hexane and ether 
$(5: 1,3 \times 50 \mathrm{~mL})$ and dried over anhydrous $\mathrm{Na}_{2} \mathrm{SO}_{4}$ Removal of the solvent left an oil containing essentially the bicyclic cyanohydrin TMS ether 14. Subsequently, the resulting oil was dissolved in $43 \mathrm{~mL}$ of $10 \%$ aqueous $\mathrm{Et}_{2} \mathrm{O}$, and $3.3 \mathrm{~mL}$ of $1 \mathrm{~mol} \mathrm{~L}-1$ to this mixture. The resulting mixture was stirred at room temperature for 3 days. After this time, water $(10 \mathrm{~mL})$ was added and the mixture was extracted with $\mathrm{Et}_{2} \mathrm{O}(3 \times 25$ $\mathrm{mL})$. The combined organic phases were dried over anhydrous $\mathrm{Na}_{2} \mathrm{SO}_{4}$ and concentrated in vacuo to give 540 $\mathrm{mg}$ of the crude product as a yellowish foam. Purification of the residue by chromatography afforded $391 \mathrm{mg}(2.65$ mmol, 75\% based over three step from starting aldehyde 13) of (-)-6.

Data for 14. IR (film) $v_{\max } / \mathrm{cm}^{-1}: 2960,2920,2850$, 1700, 1670, 1450, 1320, 1250, 1170, 1110, 890, 850, 755; ${ }^{1} \mathrm{H}$ NMR $(200 \mathrm{MHz}) \delta 0.16(\mathrm{~s}, 3 \mathrm{H}), 0.28(\mathrm{~s}, 6 \mathrm{H}), 1.26$ (s, $3 \mathrm{H}), 1.83$ (d, J $0.98 \mathrm{~Hz}, 2 \mathrm{H}), 2.12-2.48$ (m, 1H), $2.60-$ $2.79(\mathrm{~m}, 1 \mathrm{H}), 2.87(\mathrm{dq}, J 2.2$ and $16.5 \mathrm{~Hz}, 1 \mathrm{H}), 3.32(\mathrm{~d}, J$ $16.5 \mathrm{~Hz}, 1 \mathrm{H}), 3.62$ (bt, 1H), 4.83 (d, J $2.4 \mathrm{~Hz}, 1 \mathrm{H}), 4.89$ (d, $J 2.4 \mathrm{~Hz}, 1 \mathrm{H}) ;{ }^{13} \mathrm{C}$ NMR $(50 \mathrm{MHz}) \delta 1.1,13.6,29.7,30.2$, 42.3, 52.8, 53.0, 107.4, 120.7, 135.7, 139.5, 147.1 (signals reported for two diastereomers).

Data for 6. $[\alpha]_{\mathrm{D}}-199\left(\mathrm{c} 1.19, \mathrm{CH}_{2} \mathrm{Cl}_{2}\right) ; \mathrm{mp}=50-52^{\circ} \mathrm{C}$; IR (film) $v_{\max } / \mathrm{cm}^{-1}: 3440,3340,2960,2930,2850,1740$, 1690, 1650, 1590, 1430, 1370, 1290, 1190, 1030, 970, 870, 670, 570; ${ }^{1} \mathrm{H}$ NMR (200 MHz) $\delta 1.58(\mathrm{dt}, 1 \mathrm{H}, J 8.4$ and $11.5 \mathrm{~Hz}), 2.08(\mathrm{~s}, 3 \mathrm{H}) 2.10(\mathrm{~s}, 3 \mathrm{H}), 2.19(\mathrm{dt}, 1 \mathrm{H}, J 6.6$ and $11.5 \mathrm{~Hz}), 2.42(\mathrm{dd}, 1 \mathrm{H}, J 8.4$ and $16.9 \mathrm{~Hz}), 2.80-3.06$ $(\mathrm{m}, 1 \mathrm{H}), 3.55-3.75(\mathrm{~m}, 1 \mathrm{H})$ and $5.88(\mathrm{~s}, 1 \mathrm{H}) ;{ }^{13} \mathrm{C} \mathrm{NMR}(50$ $\mathrm{MHz}) \delta 15.0,16.9,29.3,42.8,55.5,133.7,141.0,145.7$, 171.7, 191.7 .

(1R,5S,8R)-4,8-dimethylbicyclo[3.3.0]oct-3-en-2-one (5)

A mixture of $6(100 \mathrm{mg}, 0.67 \mathrm{mmol})$ and $10 \%$ palladium on carbon $(10 \mathrm{mg})$ in ethanol $(20 \mathrm{~mL})$ was stirred under hydrogen $(101 \mathrm{kPa})$ for $35 \mathrm{~h}$. The reaction was carefully monitored by $\mathrm{CG}$ analysis and ${ }^{1} \mathrm{H}$ NMR spectroscopy and stopped at $c a$. $78 \%$ conversion to the ketone $\mathbf{5}$. The crude product was filtered through a pad of Celite and the filtrate was concentrated under reduced pressure $(20 \mathrm{mmHg})$ at $38{ }^{\circ} \mathrm{C}$ to give $90 \mathrm{mg}(89 \%)$ of the crude 5 as colorless oil.

$[\alpha]_{\mathrm{D}}-104\left(\mathrm{c} 1.50, \mathrm{CH}_{2} \mathrm{Cl}_{2}\right)$; IR (film) $v_{\max } / \mathrm{cm}^{-1}: 2957$, 2872, 1699, 1622, 1456, 1379, 1273, 1190, 919, 882. ${ }^{1} \mathrm{H}$ NMR $(200 \mathrm{MHz}) \delta 0.81-0.98(\mathrm{~m}, 1 \mathrm{H}), 1.02(\mathrm{~d}, J 6.8 \mathrm{~Hz}$, $3 \mathrm{H}), 1.51-1.78(\mathrm{~m}, 3 \mathrm{H}), 2.01$ (s, 3H), $2.02-2.15(\mathrm{~m}, 1 \mathrm{H})$, 2.59 (dd, $J 4.8$ and $9.7 \mathrm{~Hz}, 1 \mathrm{H}), 3.10$ (bt, 1H), 5.81 (s, 1H); ${ }^{13} \mathrm{C}$ NMR $(50 \mathrm{MHz}) \delta 15.6,17.5,27.7,32.2,37.0,50.9$, $53.7,132.4,179.6,210.2$.
(1R,4R,5R,8R)-4,8-dimethylbicyclo[3.3.0]octan-2-one (16)

A mixture of $6(100 \mathrm{mg}, 0.67 \mathrm{mmol})$ and $10 \%$ palladium on carbon $(10 \mathrm{mg})$ in ethanol $(20 \mathrm{~mL})$ was stirred under hydrogen $(810 \mathrm{kPa})$ for $24 \mathrm{~h}$. The crude product was filtered through a pad of Celite and the filtrate was concentrated under reduced pressure $(20 \mathrm{mmHg})$ at $38^{\circ} \mathrm{C}$ to give $82 \mathrm{mg}$ $(80 \%)$ of a crude mixture containing $\mathbf{1 6}$ and a minor saturated component which was not characterized.

Data for 16. IR (film) $v_{\max } / \mathrm{cm}^{-1}: 2956,1735,1458,1378$, 1260, 1160; ${ }^{1} \mathrm{H}$ NMR (200 MHz) $\delta 1.02$ (d, J 7.0 Hz, 3H), $1.11(\mathrm{~d}, J 6.1 \mathrm{~Hz}, 3 \mathrm{H}), 1.58-2.01$ (m, 5H), $2.13-2.46$ (m, $3 \mathrm{H}$ ), 2.53 (t, $J 8.4 \mathrm{~Hz}, 1 \mathrm{H}$ ), 2.73 (qui, $J 7.6 \mathrm{~Hz}, 1 \mathrm{H}$ ); ${ }^{13} \mathrm{C}$ NMR $(50 \mathrm{MHz}) \delta 16.0,16.6,24.7,31.6,35.6,37.9,46.4$, 47.0, 57.6, 221.1 For reported data of IR and ${ }^{1} \mathrm{H}$ NMR, see Ref. $^{24}$

\section{Ackowledgements}

The authors wish to thank the following Brazilian agencies for financial support: CNPq (Conselho Nacional de Desenvolvimento Científico e Tecnológico), FAPERGS (Fundação de Amparo à Pesquisa do Estado do Rio Grande do Sul) and PROPESQ - UFRGS (Pró-Reitoria de Pesquisa da Universidade Federal do Rio Grande do Sul).

\section{References}

1. Subburaj, K.; Okamoto, S.; Sato, F.; J. Org. Chem. 2002, 67, 1024 and references therein.

2. Mehta, G.; Sreenivas, K.; Chem. Commun. 2001, 1892.

3. Mehta, G.; Srinivas, K.; Tetrahedron Lett. 1999, 40, 4877.

4. Armone, A.; Nasini, G.; Vajna de Pava, O.; J. Chem. Soc., Perkin Trans. 1 1993, 2723.

5. Schulz, S.; Messer, C.; Dettner, K.; Tetrahedron Lett. 1997, 38, 2077.

6. König, G.M.; Wright, A.D.; J. Org. Chem. 1997, 62, 3837.

7. Nabeta, K.; Yamamoto, K.; Hashimoto, M.; Koshino, H.; Funatsuki, K.; Katoh, K.; J. Chem. Soc., Chem. Commun. 1998, 1485.

8. Warmers, U.; Wihstutz, K.; Bulow, N.; Fricke, C.; König, W.A.; Phytochemistry 1998, 49, 1723.

9. Warmers, U.; König, W.A.; Phytochemistry 1999, 52, 1519.

10. Nabeta, K.; Yamamoto, M.; Koshino, H.; Fukui, H.; Fukushi,Y.;Tahara, S.; Biosci. Biotechnol. Biochem. 1999, 63, 1772.

11. Fietz-Razavian, S.; Schulz, S.; Dix. I.; Jones, P. G.; Chem. Commun. 2001, 2154.

12. Mehta, G.; Srinivas, K.; Tetrahedron Lett. 2001, 42, 2855.

13. Piers, E.; Orellana, A.; Synthesis 2001, 2138. 
14. Takayanagi, H.; Kitano, Y.; Morinaka, Y.; J. Org. Chem. 1994, 59, 2700.

15. Stork, G.; Depezay, J.C.; d'Angelo, J.; Tetrahedron Lett. 1975, 6,389 .

16. Takahashi, T.; Nemoto, H.; Kanda, Y.; Tsuji, J.; Tetrahedron 1987, 43, 5499 .

17. Sakai, K.; Ishiguro, Y.; Funakoshi, K.; Ueno, K.; Suemune, H.; Tetrahedron Lett. 1984, 25, 961.

18. Hedge, S. G.; Wolinsky J.; J. Org. Chem. 1982, 47, 3148.

19. Wolinsky J.; Barker, W.; J. Am. Chem. Soc. 1960, 82, 636.
20. Wolinsky J.; Slabaugh, M. R.; Gibson, T.; J. Org. Chem. 1964, 29, 3740 .

21. Paquette, L.A.; Liang, S.; Wang, H.L.; J. Org. Chem. 1996, 61,3268

22. Davis, C.E.; Duffy, B.C.; Coates, R.M.; Org. Lett. 2000, 2, 2717.

23. Agosta, W.C.; Wolff, S.; J. Org. Chem. 1975, 40, 1699.

24. Suemune, H.; Oda, K.; Saehi, S.; Sakai, K.; Chem. Pharm. Bull. 1988, 36, 172.

Received: January 9, 2004 Published on the web: September 1, 2004 